\title{
The frequency of lactase phenotypes in Aymara children
}

\author{
ELFRIDE BALANZA AND GONZALOTABOADA
}

From the Instituto de Genetica Humana, Facultad de Medicina, Universidad Mayor de San Andrés, Box 3050, La Paz, Bolivia.

SUMMARY A total of 122 apparently healthy Bolivian Aymara-mixed children ranging in age from 2 to 12 years were tested for lactose absorption using the standard lactose tolerance test $N$ with blood glucose determination. Analysing the sample according to the age of the probands, we $\stackrel{N}{-}$ found an increased age related frequency of lactose malabsorption showing final percentages of $\mathbb{N}^{N}$ $55 \%$ in the 2 to 5 years group, $57.4 \%$ in the 6 to 10 years group, and $77.4 \%$ in the 11 to 15 years 을 group.

This report presents a study of the distribution of the lactase phenotypes in a group of Aymara-mixed children, considered to be a polymorphism of small intestinal lactose activity in human adults who have genetic and cultural co-evolution. ${ }^{1-3}$

'Primary post-weaning hypolactasia' with lactose malabsorption is common in Latin American and Asiatic populations. The population of many Latin American mixed groups has been insufficiently studied with respect to this anthropological genetic polymorphism.

In Mexico, only two surveys have been reported showing high frequencies of lactose malabsorption like the Japanese population. ${ }^{4-6}$ Although lactose tolerance with breath hydrogen determination has advantages over blood glucose determination, ${ }^{37}$ the latter was used in the present survey, because we did not have the technical resources to perform the breath hydrogen test.

\section{Materials and methods}

A total of 122 apparently healthy Bolivian Aymara mixed children were examined at the National Institute of Food and Nutrition in $\mathrm{La} \mathrm{Paz}$, Bolivia. The Aymara people inhabit a high Andean plateau in western Bolivia and south eastern Peru, over 13600 feet above sea level, and are the descendants of Tihuanacu Indians who were living in the area for many centuries before the Spanish arrived in 1533 . They have enjoyed some degree of isolation ever

Received for publication 6 December 1983 Accepted for publication 27 July 1984. since. If the history is correct, the sample has been $\vec{\varnothing}$ subject to limited admixture with white (Spanish). people.

The sample was selected from lower socioeconomic level families, who were attending a 'mother's club', and was composed of people who had migrated from the Aymara's area. The probands $\stackrel{\square}{\Phi}$ were between 2 and 12 years old. The birthplaces of $\vec{F}$ the proband's parents and grandparents were re-응 corded for geographical identification, in order to eliminate other groups who had migrated to the Aymara's area.

The total sample was divided into three groups according to age, male and female together (table $\dot{0}$ 1).

The sex distribution was unequal with $35 \%$ being male in the 2 to 5 year old group and $50 \%$ being male in the 6 to 15 year old group.

The parents of the subjects were informed of the purpose of the research and the possible complica-o tions of the tolerance test, and their consent was obtained. The standard lactose test was performed after a fast of at least six hours. Blood samples were N collected 15 minutes before and 45 minutes after anN oral load of $1.5 \mathrm{~g}$ lactose per $\mathrm{kg}$ bodyweight dis- $\sigma$ solved in $80 \mathrm{ml}$ of tap water.

TABLE 1 Age and sex distribution of the sample.

\begin{tabular}{|c|c|c|c|}
\hline Age (years) & Male & Female & Total \\
\hline $2-5$ & 7 & 13 & 20 \\
\hline $6-10$ & 37 & 34 & 71 \\
\hline $11-15$ & 15 & 16 & 31 \\
\hline Total & 59 & 63 & 122 \\
\hline
\end{tabular}


The serum glucose concentration was determined by the Nikkila Hyvarinens spectrophotometric method. Patients were characterised as lactose absorbers when the increase of glucose in the serum was $25 \mathrm{mg} / 100 \mathrm{ml}$ or more over the basal value and as lactose malabsorbers when the blood glucose increase was less than $15 \mathrm{mg} / 100 \mathrm{ml}$. Increases between 15 and $25 \mathrm{mg} / 100 \mathrm{ml}$ were considered equivocal and the tests were repeated after a week.

The criteria for classifying subjects into lactose absorbers and malabsorbers was according to Lisker and Aguilar. ${ }^{5}$ The frequency distribution histogram of serum glucose concentrations 45 minutes after the oral lactose load was bimodal and the antimode concentration was between 15 and $25 \mathrm{mg} / 100 \mathrm{ml}$. This corresponds well with the cited classification criteria for lactose absorbers and malabsorbers. The serum results were correlated with symptoms of lactose intolerance suffered during and after the lactose test, for example, meteorism, abdominal pain, and borborygmi. All of these were classified by $(+)$ when light, $(++)$ when moderate, and $(+++)$ when severe. Lactose malabsorbers were characterised by $(++++)$ or more.

\section{Results}

FREQUENCY OF LACTOSE ABSORPTION AND MALABSORPTION BY AGE GROUPS IN THE TOTAL SAMPLE

Table 2 shows the frequency of lactose absorbers and lactose malabsorbers classified by age in the total sample of 122 children.

The differences between the three age groups show an increase in the frequency of lactose malabsorption ranging from $55 \%$ in the 2 to 5 year

TABLE 2 Age and sex distribution of the lactase phenotypes.

\begin{tabular}{|c|c|c|c|c|c|c|}
\hline & & \multicolumn{3}{|c|}{ Age group (years) } & \multirow{2}{*}{$\frac{\text { Male }}{(\%)}$} & \multirow{2}{*}{$\begin{array}{l}\text { Female } \\
(\%)\end{array}$} \\
\hline & & $2-5$ & $6-10$ & $11-15$ & & \\
\hline LA & (No) & 9 & 30 & 7 & 20 & 26 \\
\hline LM & (No) & 11 & 41 & 24 & 39 & 37 \\
\hline Total & & 20) & 71 & 31 & 59 & 63 \\
\hline LM & $(\%)$ & $55 \cdot 0$ & $57 \cdot 7$ & $77 \cdot 4$ & $66 \cdot 1$ & 58.7 \\
\hline
\end{tabular}

$\mathrm{LA}=$ lactose absorber. $\mathrm{LM}=$ lactose malabsorber.

TABLE 3 Symptoms of lactose intolerance within 4 to 12 hours of lactose administration.

\begin{tabular}{|c|c|c|c|c|}
\hline & \multicolumn{2}{|c|}{ Lactose absorbers } & \multicolumn{2}{|c|}{ Lactose malabsorbers } \\
\hline & No & $\%$ & No & $\%$ \\
\hline No symptoms reported & 42 & $91 \cdot 3$ & 20 & $26 \cdot 31$ \\
\hline Symptoms $(++++)$ or more & 4 & $8 \cdot 7$ & 57 & 73.69 \\
\hline Total & 46 & 100 & 76 & 100 \\
\hline
\end{tabular}

old group to $77.4 \%$ in the 11 to 15 year old group. Lactose malabsorption is somewhat more frequent in males than in females but the difference is not significant $\left(\chi_{2}^{2}=4 \cdot 0985, \mathrm{p}<0 \cdot 10\right)$.

SYMPTOMS OF LACTOSE INTOLERANCE IN BOTH GROUPS: ABSORBERS AND MALABSORBERS

The total sample was analysed in the two groups according to symptoms of lactose intolerance experienced during and after the lactose test. As is evident from table 3 , there is a highly significant difference between lactose absorbers and malabsorbers $\left(\chi^{2}=39 \cdot 2, p>0 \cdot 01\right)$.

\section{Discussion}

Information about the distribution of the lactase phenotypes in Latin American children is scanty, especially in Bolivia.

Two studies of this distribution in populations of healthy persons less than 15 years old were made in Mexico, in which $70 \%$ were found to be lactose malabsorbers. ${ }^{56}$ This frequency corresponds well with the average percentage $(62.3 \%)$ of lactose malabsorbers observed in our, admittedly small, sample of Aymara-mixed children.

Both findings agree well with the relatively high frequency of lactose malabsorption in the young population of Japan, ${ }^{6}$ in which $85 \%$ were found to be lactose malabsorbers. These findings appear to be compatible with a high gene frequency of the trait in the gene pool of people derived from Mongolian ancestral stock.

Table 1 shows the sex distribution to be unequal in the age groups studied, with $35 \%$ male in the 2 to 5 year old group and $50 \%$ male in the 6 to 15 year old group. This unequal sex distribution could be explained by the small size of the sample in the 2 to 5 year old group.

When we compared the occurrence of the symptoms of lactose intolerance between lactose malabsorbers and lactose absorbers, we found a highly significant difference between the phenotypes (table 3 ). These results show that, in Bolivia, we should have a limit on the consumption of fresh milk as a supplementation of food intake for children who are suffering from malnutrition.

We thank Drs J Barrón, C Feraudi, and R Vera from Instituto Nacional de Alimentación (INAN) for providing the families from their Mother's Club.

\footnotetext{
References

1 Durham, EH. The interaction of biology and culture; a case study of dairying. Annual Meeting of the American Anthropological Association, Niagara Falls, New York, 1980.
} 
${ }^{2}$ Flatz G, Rotthauwe $H$. The human lactase polymorphism: physicology and genetics of lactose absorption and malabsorption. Prog Med Genet 1977;1:205-49.

${ }^{3}$ Howell YN, Schockennhoff T, Flatz G. Population screening for the human adult lactase phenotypes with a multiple breaths version of the breath hydrogen test. Hum Genet 1981;57:276-8.

${ }^{4}$ Lisker R, Aguilar L, Zabala C. Intestinal lactose deficiency and milk drinking capacity in the adult. Am J Clin Nutr 1978:31:1494-504.

s Lisker R, Aguilar L. Double blind study of milk lactose intolerance. Gastroenterology 1978;74:233-5.
${ }^{6}$ Nose O, Kai H, Harada T, Ogawa M, Yambuchi H. Breath $\stackrel{\mathbb{D}}{\overparen{D}}$ hydrogen. Test for detecting lactose malabsorption in infants and children. Arch Dis Child 1979:34:436-40.

${ }^{7}$ Levitt MD, Donalson RM. Use of respiratory hydrogen $(\mathrm{H} 2)$ excretion to detect carbohydrate malabsorption. J Lab Clin Med 1970;75:937-45.

Correspondence and requests for reprints to $\mathrm{Dr} G$ Taboada, Instituto de Genetica Humana, Facultad de Medicina, UMSA, Box 3050, La Paz, Bolivia. 